\title{
Soil Microbial Diversity and Activity Linked to Crop Yield and Quality in a Dryland Organic Wheat Production System
}

\author{
Nicole E. Tautges ${ }^{1}$, Tarah S. Sullivan ${ }^{1}$, Catherine L. Reardon ${ }^{2}$, Ian C. Burke ${ }^{1}$ \\ ${ }^{1}$ Department of Crop and Soil Sciences, Washington State University, Pullman, WA 99164 \\ ${ }^{2}$ Columbia Plateau Conservation Research Center, USDA-Agricultural Research Service, Pendleton, OR \\ 97801
}

Corresponding author: Nicole Tautges; nicole.tautges@wsu.edu

\begin{abstract}
One of the primary goals of organic agriculture is increasing soil quality through the enhancement of soil biological diversity and activity. Greater soil microbial activity and diversity increase soil organic matter turnover and contribute to soil fertility, one of the main challenges associated with organic management. The objectives of this study were to 1) compare soil microbial abundance and activity between organic and conventional cropping systems, and 2) explore connections between soil microbial community indicators and crop productivity in organic and conventional winter wheat (Triticum aestivum)/spring wheat/winter pea (Pisum sativum) rotations. Soil and plant tissue was sampled following six years of organic and conventional management, and soil was analyzed for microbial abundance and activity. Fungal and bacterial abundance, soil enzyme activity, and soil organic carbon (C) were greater in the organic system than in the conventional system, and all four measures were positively correlated. Community-level physiological profiling (CLPP) indicated that C substrate utilization was greater in the organic than in the conventional system, though bacterial T-RFLP data did not demonstrate different community structure between systems, suggesting that management type affected bacterial community function, but not structure. Fungal T-RFLP results indicated that fungal community structure was different between the organic and conventional systems. Hay yield and tissue nitrogen $(\mathrm{N})$ were greater in the organic system, and were positively correlated with fungal and bacterial abundance, but grain yield
\end{abstract}


and protein were greater in the conventional system. The results of this study indicate that management type (organic vs. conventional) has implications for microbial abundance and microbial community function, and that differences in soil microbial abundance and activity likely impact crop yields and $\mathrm{N}$ uptake.

Keywords: Carbon substrate utilization, grain yield, microbial abundance, nitrogen uptake, soil enzyme activity, T-RFLP

\section{Introduction}

A central tenet of the organic agriculture philosophy revolves around improving soil quality through building soil organic matter (SOM), enhancing biodiversity, and increasing soil biological activity (Lotter, 2003). Greater soil microbial diversity has been considered an indicator of greater overall ecosystem diversity and function, and is considered a sign of a "healthy" organic soil. Organic agriculture emphasizes the use of animal and green manures and composts to enhance soil fertility, as these materials have been shown to increase SOM (Fliessbach et al., 2007; Haynes and Naidu, 1998; Ros et al., 2006). The precise character of fertility amendments used in organic versus conventional agriculture exert a large effect on soil microbial populations, in the same way that the amount and type of organic matter inputs strongly affect soil microbial status (Shannon et al., 2002).

As SOM accumulates, ecosystem productivity can often become limited by the mineralization rate of soil humic materials (Parfitt et al., 2005), which is determined by the amount and activity of extracellular enzymes produced by soil microorganisms that break down complex organic molecules (Allison and Vitousek, 2005; Sinsabaugh, 1994). Extracellular enzyme production depends on bacterial and fungal biomass, physiological state, and species composition of the community, as well as a variety of environmental factors (Allison et al., 2007). Organic producers have reported that they struggle to maintain adequate soil inorganic $\mathrm{N}$ to achieve levels of production equal to those of conventional systems 
(Tautges and Goldberger, 2015; Walz, 2004). However, several studies report finding similar or greater total N levels in organic versus conventional soils (Gosling and Shepherd, 2005; Marinari et al., 2006; Marriott and Wander, 2006).

While total soil $\mathrm{N}$ may be greater in organic than conventional soils, $\mathrm{N}$ is usually the most limiting nutrient for crops in organic systems because much of the $\mathrm{N}$ is tied up in organic matter (Badgley et al., 2007; Seufert et al., 2012). Greater partitioning of $\mathrm{N}$ to the organic fraction may be favorable for soil health; however, a high organic to inorganic $\mathrm{N}$ ratio in soils often results in insufficient levels of available $\mathrm{N}$ for crop plants and consequently low grain yields. Mäder et al. (2002) found that the soluble fraction of $\mathrm{N}$ was lower in organic than in conventional soils, but that extracellular enzyme activity and microbial diversity was greater in organic soils. Further, they observed more complete decay of particulate organic matter and greater microbial biomass in organic systems, indicating greater turnover of SOM but not necessarily a surplus of soluble forms of nutrients. Instead, N released through mineralization is likely being immobilized via assimilation into microbial biomass (Burger and Jackson, 2003; Willson et al., 2001). For example, yield benefits are observed in grain crops when legumes are added into the crop rotation to increase soil $\mathrm{N}$ with additional $\mathrm{N}$ fertilizer. Additional soil available $\mathrm{N}$ observed following the legume crop has been attributed to turnover of microbial biomass $\mathrm{N}$, rather than the release of $\mathrm{N}$ from the legume tissues or roots (Bremer and van Kessel, 1992; Peoples et al., 2009). Some studies have found that, over time, organic systems that return large amounts of organic matter to the soil accumulate enough SOM that mineralization of SOM results in sufficient quantities of inorganic $\mathrm{N}$ that can support high-yielding grain crops (Mason and Spaner, 2006). For example, Zentner et al. (2004) found in years 5 through 12 of a long-term study that an organic spring wheat-legume green manure rotation achieved yields similar to that of a conventional spring wheat-fallow rotation. They also observed a significant increase over time in grain protein and $\mathrm{N}$ mineralization, indirectly indicating that microbial mineralization of accrued SOM can reach levels sufficient to support high-yielding organic 
crops. Therefore, soil microbial diversity and activity is of great interest in evaluating the outcomes of organic management practices on soil fertility, especially as compared to conventional management.

Perhaps not surprisingly, important biological indicators of soil health, including microbial biomass (Birkhofer et al., 2008; Fliessbach et al., 2007; Tu et al., 2006), microbial abundance (Shannon et al., 2002), enzyme activity (Marinari et al., 2006; Tu et al., 2006), microbial diversity (Mäder et al., 2002; Shannon et al., 2002), and C substrate utilization (Ros et al., 2006) have all been found to be greater in organically-managed soils than in conventionally-managed soils. Fungal biomass has also been consistently found to be greater in organic systems, compared to conventional systems (Birkhofer et al., 2008; Gunapala and Scow, 1998; Shannon et al., 2002; Yeates et al., 1997). While some studies have reported bacterial abundance to be higher in organically-managed soils (Mulder et al., 2003; van Diepeningen et al., 2006), others have found bacterial abundance to be less sensitive to management practices than fungal abundance (Yeates et al., 1997). Activity and diversity of soil microbes is, at least in part, a function of the availability, variety, and recalcitrance of $\mathrm{C}$ substrates and, as organic systems generally receive greater organic matter inputs than conventional systems (Burger and Jackson, 2003; Tu et al., 2006; Yeates et al., 1997), soils under organic management generally have a higher C content than those under conventional management. Greater soil $\mathrm{C}$ content does not necessarily imply greater microbial utilization of C, however. Birkhofer et al. (2008) found that soil C in a conventional system was more labile and therefore more easily accessible to microbes than in an organic system.

While many studies have reported differences in soil microbial biomass and diversity between organically- and conventionally-managed soils, few have examined correlations directly between these indicators. Those that have did not observe soil microbial indicators over a long-term time frame, following the conversion from conventional to organic agriculture. Long-term studies are needed to determine whether microbial soil health indicators can be linked to improved crop yield and quality outcomes. If greater soil microbial diversity and activity increase crop yield and quality, growers may be incentivized to cultivate a more diverse and functional soil microbial community, which would eventually 
also promote ecosystem health. This study aims to establish the link between soil microbial community health measures and enhanced crop yield and quality by 1) comparing soil microbial abundance and activity between organically- and conventionally-managed winter wheat (Triticum aestivum)/spring wheat/winter pea (Pisum sativum) rotations, and 2) exploring connections between soil microbial community indicators and crop productivity. The identification of these connections could substantiate the claim that greater soil health in turn contributes to greater agroecosystem function, and better crop quality and productivity.

\section{Materials and Methods}

Site Description and Treatment Design

Research was conducted at a site near Pullman, WA $\left(46^{\circ} 45^{\prime} \mathrm{N} ;-117^{0} 4^{\prime} \mathrm{W}\right)$ in the Palouse region of eastern Washington. The field was situated on a west-facing slope with the soil type Palouse silt loam (fine-silty, mixed, superactive, mesic Pachic Ultic Haploxerolls). Average annual precipitation for the area is $509 \mathrm{~mm}$ with the majority falling between November and March (Gallagher et al., 2010). The field site had been transitioned to certified organic management during an organic transitional crop rotation study conducted from 2003 to 2007 (see Gallagher et al., 2010 and Borrelli et al., 2012 for field history), after which time the field was maintained under continuous organic certification for the six-year study (2009 to 2014). At the initiation of the study period, in 2008, a conventional block was also established for comparison.

Identical organic and conventional crop rotations were designed in the study to enable direct comparisons between organic and conventional management, which differed in fertilizer and herbicide inputs. Plots were arranged in a randomized complete block design with 5 replicates of each treatment system and rotation within a block. The organic system was a certified organic three-year winter wheat/spring wheat/winter pea (hayed) rotation, similar to conventional rotations commonly grown in the region. Poultry manure (5\% total $\mathrm{N}$, with a $\mathrm{C}: \mathrm{N}$ ratio of 6 ) was applied to the winter and spring wheat 
crops at the time of planting at a rate of $4400 \mathrm{~kg} \mathrm{ha}^{-1}\left(220 \mathrm{~kg} \mathrm{~N} \mathrm{ha}^{-1}\right)$, assuming a seasonal mineralization rate of $75-80 \%$ (165 to $176 \mathrm{~kg} \mathrm{~N} \mathrm{ha}^{-1}$ ). The conventional system is the conventional mimic of the organic system, and rotates winter wheat/spring wheat/winter peas (hayed). All grain crops in the conventional system received $56 \mathrm{~kg} \mathrm{ha}^{-1}$ starter fertilizer at planting, and $112 \mathrm{~kg} \mathrm{ha}^{-1}$ urea after planting, to match the estimated $\mathrm{N}$ mineralized in one cropping season within the organic system. Herbicides were used to control weeds in the conventional system. Glyphosate was applied each year prior to planting, pyrasulfotole, bromoxynil, and pinoxaden were applied post-emergence in spring wheat, and metribuzin was applied post-emergence in winter pea. A cultivator was used to prepare the seedbed for planting in both systems. All tillage operations in both systems were performed at depths of $10 \mathrm{~cm}$ or less to conserve soil, and no inversion tillage was utilized at any point throughout the duration of the study.

Rotations were replicated twice by establishing cropping sequences that started with different crops in the rotation. For example, rotation replicate 1 of each system was planted to winter peas, and rotation replicate 2 to spring wheat, so that crops within the rotations were replicated in time and space (Posner et al., 2008). The conventional blocks were separated from the organic blocks by a 50-foot-wide buffer to satisfy certified organic production standards. While organic and conventional system plots were not randomized amongst each other due to the USDA National Organic Program (NOP) rules, the systems were located in the same field and soil total C (TC) and total N (TN) content was not different between plots in the organic and conventional blocks at the initiation of the study in 2008 .

\section{Plant Tissue Sampling and Analysis}

In early June of 2014, rotation replicates 1 and 2 of the organic and conventional systems were in spring wheat and winter peas, respectively. Consequently, plant productivity measures were taken from those two crops to have simultaneous measures of soils and plant tissues. At this time, prior to harvest, winter pea tissue was sampled by clipping three $0.1-\mathrm{m}^{2}$ quadrats per plot, separating the peas from the weeds, drying, and weighing to calculate dry matter yields. Dry pea tissue was ground and tissue $\mathrm{N}$ analyzed using a dry combustion auto analyzer (TruSpec CN Determinator; LECO Corporation St. 
Joseph, MI). Winter pea was harvested for hay in mid-June in both systems by swathing and baling, which was performed immediately after soil samples were collected. Bales were removed from plots and marketed, similar to other hay harvesting operations performed in the region. Wheat grain was harvested at maturity and yields measured with a plot combine, and grain samples were collected from each plot. Grain protein was analyzed using near-infrared spectroscopy (NIRS).

\section{Soil Sampling and Analysis}

Soil sampling was conducted in the fall following grain harvest in each year of the long-term study, but microbial analysis was conducted only in the final year of the study (2014), the results of which are reported here. Soil for microbial analysis was collected simultaneously with plant tissue sampling in early June 2014, in the sixth year of the rotation study. Three soil cores per plot were sampled in-row to a depth of $30 \mathrm{~cm}$ with a Zero Contamination system with 1-inch plastic sleeves from Giddings (Giddings Machine Company, Windsor, CO). Cores were divided into 0-15 cm and 15-30 cm fractions, composited by depth, homogenized, and transported on ice, in the dark, to the lab for further analyses. After aseptically sieving each sample to $2 \mathrm{~mm}$ to remove stones and plant debris, samples were partitioned for microbial analyses, soil $\mathrm{C}$ and N, moisture, and $\mathrm{pH}$ analysis. Gravimetric soil water content was determined using $30.0 \mathrm{~g}$ dried at $55^{\circ} \mathrm{C}$, and 5 replicates of $0.30 \mathrm{~g}$ dry soils were analyzed for total $\mathrm{N}$ (TN) and C (TC) content using a dry combustion auto analyzer (TruSpec CN Determinator; LECO Corporation St. Joseph, MI). Soil pH was determined by the saturated paste method of Thomas (1996).

\section{Soil Genomic DNA Extraction}

Extractions for soil microbial DNA were performed on $0.25 \mathrm{~g}$ of each sample using a MoBio PowerSoil $^{\mathrm{TM}}$ DNA extraction kit (MoBio Laboratories, Inc., Carlsbad, CA, USA) according to the manufacturer's instructions. Two $\mu$ l of each extracted DNA sample was then quantified using a NanoDrop 2000 UV-vis spectrophotometer (Thermo Scientific, Wilmington, DE, USA). DNA extracts 
were diluted with nuclease-free water 1:10 for QPCR, or to approximately 2-4 $n g \mathrm{~L}^{-1}$ for community composition analysis, and immediately frozen at $-20^{\circ} \mathrm{C}$ until analysis.

\section{Quantification of Bacterial and Fungal Gene Copy Numbers}

Abundance of either bacterial or fungal rRNA genes was determined by quantitative polymerase chain reaction (QPCR) analysis and used as a proxy to estimate relative abundance of fungal and bacterial populations in soil. QPCR runs were set up in clear low-profile 96-Well PCR Plates (Bio-Rad, Hercules, CA, USA) using $10 \mu \mathrm{l} \mathrm{SsoAdvanced}{ }^{\mathrm{TM}}$ Universal SYBR Green Supermix (Bio-Rad), $6 \mu \mathrm{H}_{2} \mathrm{O}, 1 \mu \mathrm{l}$ of forward primer, $1 \mu \mathrm{l}$ of reverse primer $(500 \mathrm{nM})$ and $2 \mu 1$ of sample. Primers used for 16S rRNA bacterial genes were EUB338 (5'-ACT CCT ACG GGA GGC AGC AG-3'; Lane, 1991) and Eub518 (5'-ATT ACC GCG GCT GCT GG-3'; Muyzer et al., 1993); and for fungal rRNA genes were nu-SSU-1196F (5'GGA AAC TCA CCA GGT CCA GA-3') and nu-SSU-1536R (5'-ATT GCA ATG CYC TAT CCC CA3') (Borneman and Hartin, 2000). Amplicon sizes were approximately $180 \mathrm{bp}$ for bacteria and $340 \mathrm{bp}$ for fungi. Samples were analyzed in triplicate with duplicate standard curves.

Thermocycling was performed on a CFX96 Real Time System with a C1000 Touch Thermal Cycler (BioRad) and the following program: denaturation at $95^{\circ} \mathrm{C}$ for $3 \mathrm{~min}$, followed by 40 cycles of $95^{\circ} \mathrm{C}$ for $30 \mathrm{sec}$, annealing at $58^{\circ} \mathrm{C}$ for fungi or $53^{\circ} \mathrm{C}$ for bacteria for $30 \mathrm{sec}$, and elongation at $72^{\circ} \mathrm{C}$ for 1 min. All samples were tested for inhibition by comparing undiluted gDNA results against 1:10 dilutions, and no inhibition was observed as both produced similar results. Standard curves were prepared by dilution of genomic DNA extracted from Escherichia coli (bacterial quantification) and Saccharomyces cerevisiae (fungal quantification) and exhibited a linear relationship between the log of the rRNA-gene copy number and the calculated threshold $(\mathrm{Ct})$ value $\left(\mathrm{R}^{2}>0.95\right)$, and amplification efficiencies ranged from $90-100 \%$.

\section{Community Level Physiological Profiling}


To determine the degree to which the physiology of the cultivable soil microbial community from each management system facilitated the mineralization of different types of C substrates, CLPP was undertaken using BIOLOG® EcoPlates ${ }^{\mathrm{TM}}$ (Biolog, Inc., Hayward, CA) according to the modified protocol of Choi and Dobbs (1999). Each EcoPlate is a 96-well microtitre plate containing 31 different carbon substrates and a control, replicated three times. Substrates are primarily amino acids $(n=6)$ carbohydrates $(n=10)$, and carboxylic acids $(n=7)$. Each well was inoculated with $100 \mu 1$ of a $10^{-3}$ soil dilution prepared in sterile physiological saline $(0.85 \% \mathrm{NaCl})$. The plates were incubated in the dark at $25^{\circ} \mathrm{C}$, and the optical density $(590 \mathrm{~nm})$ was recorded for each well every $24 \mathrm{~h}$ until most wells had reached maximum color development using a microtitre plate reader (Biotek Instruments, Inc., Winooski, VT).

Terminal Restriction Fragment Length Polymorphisms

Soil microbial community composition was characterized by terminal restriction fragment length polymorphism (T-RFLP) analysis (Marsh, 1999). Bacterial 16S rRNA genes were targeted for amplification from soil DNA extracts by PCR using the WellRED D2-labeled (Sigma-Aldrich, St. Louis, MO, USA) forward primer 8F (5'-AGA GTT TGA TCC TGG CTC AG-3') (Edwards et al., 1989) and unlabeled reverse primer 907R (5’-CCG TCA ATT CMT TTR AGT TT-3’) (Lane et al., 1985).

Duplicate $50 \mu \mathrm{L}$ reactions of each sample were amplified using either a BioRad T100 or MyCyler thermal cycler (BioRad Laboratories) and the following program: denaturation at $94^{\circ} \mathrm{C}$ for $5 \mathrm{~min}$, followed by 27 cycles of $94^{\circ} \mathrm{C}$ for $45 \mathrm{sec}$, annealing at $56^{\circ} \mathrm{C}$ for $45 \mathrm{sec}$, and elongation at $72^{\circ} \mathrm{C}$ for $1 \mathrm{~min}$, with a final extension for $10 \mathrm{~min}$ at $72^{\circ} \mathrm{C}$. The final concentrations of the reagents for each reaction was as follows: $0.05 \mathrm{U}$ Taq polymerase (New England Biolabs), 1x PCR buffer, $2 \mathrm{~m} M \mathrm{MgCl}^{2}, 0.2 \mu \mathrm{M}$ deoxy-nucleotide triphosphates (dNTPs), $0.1 \mu \mathrm{g} \mu \mathrm{L}^{-1}$ bovine serum albumin (BSA, New England Biolabs, Inc., Ipswich, MA, USA), $0.1 \mu \mathrm{M}$ of each primer, $33 \mu \mathrm{L}$ nuclease-free water (Promega, Madison, WI, USA) and $5 \mu \mathrm{L}$ of sample template at $2-4 \mathrm{ng} \mu \mathrm{L}^{-1} \mathrm{DNA}$.

The fungal internal transcribed spacer (ITS) region was amplified using the WellRED D3-labeled 
(Sigma-Aldrich) forward primer ITS1F (5’-CTT GGT CAT TTA GAG GAA GTA A-3 $3^{\prime}$ ) and unlabeled reverse primer ITS4 (5'-TCC TCC GCT TAT TGA TAT GC-3') (Mitchell et al., 1994). Duplicate $50 \mu \mathrm{L}$ reactions of each sample were amplified using a BioRad T100 thermal cycler (BioRad) and the following program: denaturation at $94^{\circ} \mathrm{C}$ for $5 \mathrm{~min}$, followed by 30 cycles of $94^{\circ} \mathrm{C}$ for $30 \mathrm{sec}$, annealing at $51^{\circ} \mathrm{C}$ for $45 \mathrm{sec}$, and elongation at $72^{\circ} \mathrm{C}$ for $45 \mathrm{~s}$, with a final extension for $10 \mathrm{~min}$ at $72^{\circ} \mathrm{C}$. The final concentrations of the reagents for each reaction was as follows: $0.1 \mathrm{U}$ Taq polymerase (New England Biolabs), 1x PCR buffer, $3 \mathrm{mM} \mathrm{MgCl}{ }^{2}, 0.6 \mu \mathrm{M}$ dNTPs), $0.1 \mu \mathrm{g} \mu \mathrm{L}^{-1} \mathrm{BSA}$ (New England Biolabs), $0.2 \mu \mathrm{M}$ of each primer, $27.5 \mu \mathrm{L}$ nuclease-free water (Promega, Madison, WI, USA) and $5 \mu \mathrm{L}$ of sample template at $2-4 \mathrm{ng} \mu \mathrm{L}^{-1}$ DNA.

Restriction enzyme digests of bacterial and fungal amplicons were performed in a final reaction volume of $20 \mu \mathrm{L}$ and reagent concentrations as follows: $0.25 \mathrm{U}$ mL-1 of Sau96I (bacteria) or HhaI (fungi) enzyme (New England Biolabs), 1x enzyme-specific buffer, $0.1 \mu \mathrm{g} \mu \mathrm{L}^{-1}$ of BSA, $8.5 \mu \mathrm{L}$ nuclease-free water and $12.5 \mu \mathrm{L}$ of PCR product at approximately $25 \mathrm{ng}_{\mu} \mathrm{L}^{-1}$. Enzyme digestion was carried out in a BioRad T100 thermal cycler at $37^{\circ} \mathrm{C}$ for $4-5 \mathrm{hr}$ with a final step of $70{ }^{\circ} \mathrm{C}$ for 15 min to heat inactivate the enzymatic reaction. Complete digestion of the DNA was verified gel electrophoresis of digested product in a $1.5 \%$ agarose gel.

Duplicate digests for each sample were pooled and lyophilized for storage at $-20^{\circ} \mathrm{C}$. Prior to analysis, the digests were dissolved in nuclease-free $\mathrm{H}_{2} \mathrm{O}$ and desalted with glycogen and EtOH. The pellets were resuspended in $20 \mu \mathrm{L}$ Sample Loading Solution (SLS, SCIEX, Framingham, MA, USA). For fragment analysis, $10 \mu \mathrm{l}$ (bacteria) or $2 \mu \mathrm{l}$ (fungi) of each pooled digest were loaded into duplicate wells with $0.25 \mu \mathrm{L}$ DNA Size Standard 600 (SCIEX) and brought to a final volume of $20 \mu \mathrm{L}$ with SLS. Separation was performed using a CEQ 800 Genetic Analyzer (Beckman Coulter, Indianapolis, IN, USA) according to the methods of Reardon and Wuest (2016).

\section{T-RFLP Data Processing and Analysis}

T-RF length profiles for soil bacteria and fungi were loaded into the online T-RFLP processing 
software T-REX (Culman et al., 2009) for noise filtering and peak alignment. In brief, T-REX uses the approach outlined by Abdo et al. (2006) to distinguish background noise from true peaks, where true peaks are identified as those whose height or area exceeds the standard deviation computed for all peaks and multiplied by the factor specified. The peak area standard deviation multiplier used in this case was 1 (the standard T-REX default). The peak alignment was based on the approach taken by the software program T-Align (Smith et al., 2005) and was utilized with a clustering threshold of 0.5. The T-Align method is often performed to account for T-RF length drift (Kaplan and Kitts, 2003; Marsh, 2005) and the version of the algorithm implemented here allows more than one peak from the same sample to be assigned to the same T-RF length bin. Of 35 samples, we found a total of 582 individual and different TRF peaks with an average of $161 \mathrm{~T}$-RFs per sample. The minimum number of T-RFs in a sample was 73 , and the maximum number of T-RFs in a sample was 201. After noise filtering and peak alignment, soil microbial T-RFLP pattern discrimination was determined using strictly presence/absence of peaks by nonmetric multidimensional scaling (NMS) analysis applied using the Jaccard distance measure and the Medium Autopilot mode in PC-Ord (MjM Software Design, Gleneden Beach, OR, USA). The Medium Autopilot mode specifies: (i) Maximum number of iterations $=200$, (ii) Instability criterion $=0 \_0001$, (iii) Starting number of axes $=4$, (iv) Number of real runs $=15$ and (v) Number of randomized runs $=30$. Unlike other commonly-used ordination techniques (e.g. principal components analysis), NMS does not assume a linear relationship among ecological variables, which allows virtually any distance measure to be used in the construction of the similarity matrix and is currently considered the most appropriate analysis for T-RFLP data sets (Culman et al., 2008; Duchicela et al., 2013). We repeated the analysis five times to confirm that we obtained consistent results.

Soil Enzyme Analysis

To supplement the results of CLPP, the activity of soil enzymes involved in phosphorus (P), C, and $\mathrm{N}$ cycling were quantified using $p$-nitrophenyl-labeled substrates. Acid phosphatase (P cycle), $\beta$ glucosidase ( $\mathrm{C}$ cycle), and $\mathrm{N}$-acetyl- $\beta$-D-glucosaminidase ( $\beta$-glucosaminidase; $\mathrm{C}$ and $\mathrm{N}$ cycles) were 
analyzed in field moist soil using a protocol modified from previous methods (Parham and Deng, 2000; Tabatabai, 1994) to accommodate smaller volumes (Reardon and Wuest, 2016). Enzyme activities are presented as the amount of nitrophenol produced per g dry soil per hour ( $\mu \mathrm{g} \mathrm{NP} \mathrm{g}^{-1}$ dry soil hr-1).

\section{Statistical Analysis}

Statistical comparisons were performed in SAS Version 9.4 (SAS Institute Inc. 2013) using PROC MIXED to perform ANOVA, and PROC REG for linear regression analysis of soil and crop parameters against each other, and against each microbial community ordination axis. System (organic vs. conventional) and crop (spring wheat vs. winter peas) were treated as fixed factors, and block was treated as a random factor. Fungal and bacterial rRNA gene copy numbers were log transformed to satisfy the assumption of equal variances, prior to statistical analysis. Given the high levels of variability inherent in such crop rotations under non-irrigated conditions, an alpha value of 0.10 was considered statistically significant in ANOVA and regression analyses.

To compare the diversity of substrates being utilized between systems, Shannon's diversity index (H) was calculated for substrate utilization using the equation $H=-\sum p_{i}\left(\ln p_{i}\right)$ where $p_{i}$ is the ratio of the absorbance value of each plate well to the sum of the absorbance values of all the wells inoculated with soil from a plot (Ros et al., 2006). All 31 substrates on the BIOLOG plates were included in the Shannon's diversity index calculations.

\section{Results}

\section{Plant Productivity and Soil Chemistry}

Soil $\mathrm{pH}$ was acidic across the site, but was lower $(\mathrm{p}=0.001)$ in the conventional system $(\mathrm{pH}=$ 4.7) than in the organic system $(\mathrm{pH}=5.0)$. In the 2014 soil samples, soil percent $\mathrm{TC}$ and $\mathrm{TN}$ were similar among organic $(1.86 \% \mathrm{C}$ and $0.157 \% \mathrm{~N})$ and conventional systems $(1.69 \% \mathrm{C}$ and $0.194 \% \mathrm{~N})$, though a difference in TC $(\mathrm{p}<0.001)$ between the organic and conventional systems was detected when soil samples from the duration of the study (2009 through 2014) were pooled and analyzed (Table 1). Spring 
wheat grain yield and protein were greater in the conventional system compared to the organic system, but pea hay yield and tissue $\mathrm{N}$ were greater in the organic system (Table 2).

\section{Bacterial and Fungal Abundance}

Bacterial and fungal abundance, as well as fungal to bacterial ratios, were all significantly greater in the organic system than the conventional system (Figure 1). No difference in fungal and bacterial abundance was observed between crop type (spring wheat vs. winter pea), nor was there an interaction between management system and crop (data not shown). Fungal and bacterial abundance was not correlated with soil TN but both were positively correlated with soil $\mathrm{TC}\left(\mathrm{p}=0.035, \mathrm{r}^{2}=0.276\right.$ for fungi and $\mathrm{p}=0.033, \mathrm{r}^{2}=0.433$ for bacteria). Fungal and bacterial abundance were both positively correlated with pea hay yield ( $\mathrm{p}=0.003$ for fungi and $\mathrm{p}=0.001$ for bacteria) (Figure 2 ). Pea hay yield was also positively correlated with soil TC $(\mathrm{p}=0.083)$. Pea hay yield regressed with bacterial abundance alone resulted in the most parsimonious model following stepwise multiple regression with all three variables (bacterial abundance, fungal abundance, and soil TC), suggesting that bacterial abundance is having the greatest positive effect on pea hay yield of the variables measured.

\section{CLPP and Community Composition}

Within the CLPP analysis, substrate utilization was significantly greater in the organic system than the conventional system for 15 of the 31 substrates on the BIOLOG plates (Table 3). Nine of the fifteen substrates utilized to a greater extent in the organic system than the conventional system were carbohydrates and carboxylic acids. L-asparagine was the only substrate on the BIOLOG plate that was utilized more by microbes in the conventional than the organic soils. Substrate utilization diversity, calculated with the Shannon's diversity index, was greater in the organic system than in the conventional system $(\mathrm{p}<0.001)$ (Figure 3), and did not differ between crops.

Multivariate analysis of all substrates for CLPP also showed a gradient between the organic and conventional systems based on differences in soil $\mathrm{pH}$ and soil TN (Figure 4), while differences between 
crops were not reflected in the ordination. Substrate utilization patterns of soil microbial communities in organically-managed soils were exclusively grouped in the negative region of axis 2 while microbial communities from conventionally-managed soils exhibited a wider distribution in the positive region of axis 2 and across both the positive and negative regions of axis 1 (Figure 4). There was a negative correlation between soil TN and the substrates D-cellobiose $\left(\mathrm{p}=0.098, \mathrm{r}^{2}=0.162\right)$, glucose-1-phosphate $\left(\mathrm{p}=0.024, \mathrm{r}^{2}=0.234\right)$, and D-galactonic acid $\mathrm{\gamma}$-lactone $\left(\mathrm{p}=0.019, \mathrm{r}^{2}=0.299\right)$. Additionally, a slight positive trend was observed between utilization of the substrates D- cellobiose and glucose-1-phosphate and pea tissue percent $\mathrm{N}(\mathrm{p}=0.091$ and $\mathrm{p}=0.057$, respectively) (Figure 5).

While separation between the community composition of the organic and conventional soil bacterial communities was not apparent in the multivariate analysis of bacterial T-RFLPs, and these communities appeared completely interspersed, the joint-plot vector indicates a gradient with regard to the concentration of extracellular $\beta$-glucosidase in those soils produced by the microbial communities (Figure 6). Conversely, fungal communities of the conventional and organic systems did display distinct community compositions according to the T-RFLP patterns, with the soil fungal community of conventionally-managed soil grouped along the positive region of axis 1 and that of the organicallymanaged soil grouped along the positive region of axis 2 (Figure 7). Additionally, joint-plot vectors indicate soil fungal communities grouped within the ordination along a gradient with increasing grain yield.

Soil Enzyme Activity

Soil enzyme activity varied significantly between the two systems for only one of the three enzymes tested. Activity of acid phosphatase, $\beta$-glucosidase, and $\beta$-glucosaminidase was numerically greater in the organic than conventional system although the difference was significant only for $\beta$ glucosaminidase (Table 4). No difference in activity for any of the three enzymes was detected between crops. $\beta$-glucosaminidase activity was the only enzyme that correlated to other measured parameters. Weak positive correlations were observed between $\beta$-glucosaminidase, fungal $\left(p=0.038, r^{2}=0.217\right)$ and 
bacterial abundances $\left(\mathrm{p}=0.033, \mathrm{r}^{2}=0.230\right)$. A slight negative trend was observed between percent protein of the spring wheat grain and $\beta$-glucosaminidase activity $(\mathrm{p}=0.048)$ (Figure 8).

\section{Discussion}

The difference between organic and conventional soil inputs exerted an effect on soil $\mathrm{pH}$. Application of urea in the conventional system resulted in a lower soil $\mathrm{pH}$ than that of the organicallymanaged soil, which received poultry manure as a fertility amendment in this study. While the $\mathrm{pH}$ difference between the conventional and organic systems in our study was fairly minimal, ( $<1.0 \mathrm{pH}$ unit), soil $\mathrm{pH}$ is often termed the "master variable" in soils and has a dramatic impact on most other measured variables, including soil microbial composition and activity (Dick et al., 2000). Greater soil acidity in the conventionally-managed soils likely impacted bacterial abundance, as Rousk et al. (2010) observed bacterial abundance and diversity to be affected by soil $\mathrm{pH}$ to a greater extent than fungal communities. As a result, the large difference in fungal abundance between organically- and conventionally-managed soils observed in this study was likely not a direct result of soil $\mathrm{pH}$, but more likely related to the forms and availability of soil $\mathrm{C}$. The $\mathrm{pH}$ difference between the organic and conventional systems may not have been great enough to significantly affect bacterial community composition, as little separation between bacterial communities' T-RFLP patterns was observed in the organic and conventional systems. However, the physiology of the bacterial community was impacted as reflected in the CLPP and enzyme assays, and likely $\mathrm{N}_{2}$ fixation as well.

While the difference in soil $\mathrm{pH}$ between the organic and conventional systems was only 0.3 on average, the small increase in soil acidity likely contributed to the lower pea hay yields observed in the conventional system. In a study conducted in northern Idaho, pea was observed to be intolerant to soil $\mathrm{pH}$ values of less than 5.5, whereas winter wheat was observed to be more tolerant to soil acidity (Mahler and McDole, 1987). The authors attributed these differences in soil acidity tolerance between pea and wheat to the shallower rooting of pea, which would restrict pea root growth to the acidic zone where $\mathrm{N}_{2}$ fixation through symbiosis with Rhizobium leguminosarum was inhibited (Mahler and McDole, 1985). As a 
strong relationship was observed between pea hay yield and bacterial abundance, and pea hay yield was lower in conventional pea than in organic pea, it is likely that Rhizobia abundance and activity was inhibited in the conventional system. The lower $\mathrm{N}$ content of conventional pea tissue, as compared to organic pea tissue, indicates that $\mathrm{N}_{2}$ fixation was lower in conventional peas and supports the contention that the nitrogenase enzyme, required for Rhizobia to effectively fix $\mathrm{N}_{2}$, was inhibited in the conventionally-managed soils.

Greater fungal abundance observed in the organically-managed than the conventionally-managed soils supports the similar findings of Yeates et al. (1997) and Shannon et al. (2002), although disagreement does exist (Frank-Snyder et al., 2001; Gunapala and Scow, 1998). Microbial populations generally shift toward bacteria-dominated communities as pH increases (Haynes and Naidu, 1998), which could explain the higher bacterial abundance found in the organic system, as compared to the conventional system. However, $\mathrm{pH}$ change coupled with soil TC together explain why fungal abundance was also greater in the organic than the conventional system. Both fungal and bacterial copy numbers were correlated with soil TC, suggesting that the higher quantity of TC in organically-managed soils supported larger bacterial and fungal populations than conventionally-managed soils. The difference in soil TC and, by extension, SOM, was likely the driver of the separation between fungal community structures of organically- and conventionally-managed soils.

Greater fungal abundance in the organic system, compared to the conventional system, may have also been due to increased mycorrhizal symbioses with plant roots, as several studies have found organic soil amendments to increase arbuscular mycorrhizal fungal colonization and fungal biomass, compared to soils amended with mineral fertilizers (Gryndler et al., 2006; Mäder et al., 2002; Muthukumar and Udaiyan, 2000; Oehl et al., 2004). Management strategy had an impact on fungal community composition but not on bacterial community composition, indicating that fungi may have been more sensitive to management inputs or differences in the soil chemistry. The correlation between pea hay yield and fungal abundance found in soils collected in-row in pea suggests that soil fungi may be providing a benefit to pea 
roots. Xavier and Germida (2003) identified increased pea yields when pea roots were colonized by mycorrhizae, relative to non-colonized plants. There is little information in the literature regarding a link between free-living soil fungi to plant growth or productivity outcomes. Given the positive correlation between fungal abundance and pea biomass accumulation observed in the organic system, more studies are needed to explore the connection between soil fungi and plant growth in agricultural systems. Further, the strong correlation between bacterial abundance and pea hay yield suggests that bacteria were providing benefits to pea plants. It is possible that Rhizobia bacteria were collected in the samples, which would mediate greater $\mathrm{N}$ availability to pea plants via atmospheric $\mathrm{N}_{2}$ fixation. Greater $\mathrm{N}_{2}$ fixation in organic peas could explain the significantly greater $\mathrm{N}$ tissue content of organic pea, compared to conventional pea, observed in this study, as Rhizobia and nitrogenase activity are very sensitive to soil pH. Drinkwater et al. (1998) also observed greater $\mathrm{N}_{2}$ fixation by organic legumes, compared to conventional legumes. Alternatively, greater bacterial and fungal abundance in the organic system could have led to greater SOM turnover and increased availability of nutrients to organic pea, which resulted in greater yield and $\mathrm{N}$ content than was observed in conventional pea. More work is needed to mechanistically identify specific soil microbial processes that directly benefit legume growth and quality.

$\beta$-glucosidase is produced by bacteria and fungi (Knight and Dick, 2004) and is an important enzyme in C cycling in soil, as it catalyzes the final step in breaking down cellulose to glucose (Esen, 1993), releasing a labile $C$ energy source for soil microbes. $\beta$-glucosidase activity in organically-managed soils were $40 \%$ greater than in conventionally-managed soils, which could indicate increased C cycling in organic soils compared to conventional soils, though organic $\mathrm{C}$ pools were not examined in this study. $\beta$ glucosidase is positively correlated with soil organic C (Stott et al., 2009), so elevated levels of activity of $\beta$-glucosidase in organically-managed soils, compared to conventionally-managed soils, may be related to the higher soil TC present in the organic system. Higher soil TC may have supported greater bacterial and fungal numbers, which in turn produced more $\beta$-glucosidase. 
$\beta$-glucosaminidase is involved in $\mathrm{C}$ and $\mathrm{N}$ cycling, and activity in soil has been found to increase following the addition of organic amendments to soils, with the greatest activity levels observed with the application of organic plant materials, followed by poultry manure (Martens et al., 1992). Produced by both bacteria and fungi, $\beta$-glucosaminidase degrades chitin (Parham and Deng, 2000) and may be involved in $\mathrm{N}$-acquiring activities of soil microbes (Sinsabaugh and Moorhead, 1995). Greater activity of $\beta$-glucosaminidase found in the organic system, compared to the conventional system, was likely due to higher soil TC in the organic system as $\beta$-glucosaminidase concentration was correlated with soil TC. Ekenler and Tabatabai (2002) also found a correlation between $\beta$-glucosaminidase activity and soil organic $\mathrm{C}$, as well as with soil organic $\mathrm{N}$, and observed that $\beta$-glucosaminidase plays a major role in $\mathrm{N}$ mineralization in soils. While no correlation between soil TN and $\beta$-glucosaminidase activity was found in this study, the negative correlation between wheat grain protein and $\beta$-glucosaminidase activity suggests that $\mathrm{N}$ released from chitin degradation into the soil solution may have been rapidly taken up and assimilated by soil microbes, and was not available to the spring wheat during grain fill. In this way, the lower yields and grain protein often observed in organic cropping systems (Mason and Spaner, 2006) may be due to decreased soil $\mathrm{N}$ availability to crop plants from increased competition with soil microbes. However, the relationship between $\beta$-glucosaminidase activity and wheat grain protein was slight, and more research should be conducted to investigate if increased soil microbial activity in organicallymanaged soils leads to increased competition with crops for soil N.

A similar dynamic was observed with substrate utilization of D-cellobiose, D-xylose, glucose-1phosphate, and D-galactonic acid y-lactone, which were negatively correlated with soil TN. Additionally, a positive trend was observed between substrate utilization of D-cellobiose and glucose-1-phosphate with pea tissue percent N. Microbial utilization of these substrates may have stimulated greater mineralization of soil organic matter by microbes, releasing $\mathrm{N}$ which then became available for plants. Consequently, greater utilization of these substrates in the organic system than the conventional system may have contributed to greater pea tissue $\mathrm{N}$ in organic pea, though the link between microbial utilization of these 
two sugars and pea $\mathrm{N}$ uptake is unclear. While $\mathrm{N}$ mineralization was not measured in this study, the similar levels of soil TN observed between the organic and conventional systems could be due to increased $\mathrm{N}$ cycling in the organic system. Soil $\mathrm{N}$ dynamics in the organic system seemed to more adequately satisfy the $\mathrm{N}$ requirements of pea than in the conventional system, though the opposite was true for spring wheat. The discovery of certain soil microbial activities that could be linked to increased plant nutrient availability would have significant benefits for crop production. While our results from the BIOLOG plates are culture-dependent, future studies should investigate specific soil microbiological processes that increase plant nutrient availability in the field.

The community level physiological profile showed that diversity and rate of C substrate utilization was greater in the organic system soil microbial communities, where a difference in utilization of 16 substrates was observed between the organic and conventional systems. Although there are drawbacks to the CLPP method, such as the exclusion of fungal activity and culture-dependency (Nannipieri et al., 2003), the organic system promoted greater C substrate utilization than the conventional system, which was in agreement with extracellular enzyme activity measurements. Greater utilization of $\mathrm{C}$ substrates by microbes in the organically-managed soils was likely due to greater soil TC as a consequence of manure application (Gomez et al., 2006), and possibly to greater concentrations of soil enzymes in the organically-managed soils. $\beta$-glucosidase is known to catalyze the decomposition of D-cellobiose and D-xylose, and $\beta$-glucosaminidase is known to catalyze the decomposition of $\mathrm{N}$-acetylD-glucosamine, the decomposition products of which provide microbes with $\mathrm{N}$ and $\mathrm{C}$. Xylose is produced mostly by plants (Puget et al., 1999), so greater utilization of D-xylose by organisms in organic soils may indicate greater priming within that community for cycling of plant-derived sugars or residues. Carbohydrates and carboxylic acids were the $\mathrm{C}$ source guilds where differences in utilization between organically- and conventionally-managed soils were most commonly detected in this study. Ros et al. (2006) also observed greater utilization of carboxylic acids in soils amended with organic materials, compared to soils amended with mineral fertilizers. While T-RFLP analysis did not reveal separation of 
bacterial communities between the organic and conventional systems, the NMS analysis of C substrate utilization did show separation of bacterial activity between organically- and conventionally-managed soils, which suggests that though bacterial community composition was similar between the organic and conventional system, the activity and function of the overall microbial community was different between the two systems. Further, the lack of separation of bacterial C substrate utilization patterns between spring wheat and winter pea shows that management strategy (organic vs. conventional) is driving substrate utilization more than crop species or root exudates. It is likely that the poultry manure inputs present in the organic system and absent in the conventional system are affecting SOM quality and quantity, which in turn can affect bacterial $\mathrm{C}$ utilization patterns. Differences in SOM quality resulting from the poultry manure may also be driving the differences in fungal community structure observed between the organic and conventional systems. Although the design of this study did not enable definitive separation of the effects of the differences between the two management strategies, it is clear that the two strategies produce distinguishable differences in aboveground yields and belowground communities.

\section{Conclusions}

The results of this study found greater soil microbial abundance and activity in manure-amended organically-managed soils than in conventional soils receiving synthetic $\mathrm{N}$ fertilizer. The accompaniment of $\mathrm{N}$ fertilizer inputs with $\mathrm{C}$ sources likely stimulated microbial activity and provided a more optimal balance of $\mathrm{C}$ and $\mathrm{N}$ for microbial growth requirements. While no relationship between microbial activity and grain yield or quality was observed in spring wheat, greater microbial activity likely increased biomass accumulation and $\mathrm{N}$ fixation in the winter pea crop, both of which were greater in organicallymanaged than conventionally-managed soils. Greater N uptake in the legume crop may have been mediated by mycorrhizal, Rhizobial, or other yet-to-be-identified soil microbial taxa that are beneficial for plant growth. Soil microbial diversity and activity are important factors involved in increasing soil quality under organic production principles, and these processes require further characterization. The results of this study suggest that management practices that lead to increased soil microbial abundance and activity 
can have direct benefits for a legume (pea) crop, and could lead to greater returns for growers. Increased adoption of organic agriculture or more widespread use of organic soil amendments in conventional production systems could occur if quantifiable benefits for crop yield and quality are identified as a result of increased soil microbial diversity and activity.

\section{Acknowledgements}

The authors would like to thank Shane Hetrick, Jeanene DeAvila, and Elizabeth Torres for their technical expertise and assistance in the lab. Also, thanks to the anonymous reviewers whose comments improved this manuscript. Funding for the project was provided by USDA-NIFA Organic Agricultural Research and Extension Initiative (OREI) grant 2009-51300-05578.

\section{Literature Cited}

Abdo, Z., Schuette, U.M.E., Bent, S.J., Williams, C.J., Forney, L.J., Joyce, P., 2006. Statistical methods for characterizing diversity of microbial communities by analysis of terminal restriction fragment length polymorphisms of 16S rRNA genes. Environ. Microbiol. 8, 929-938.

Allison. V.J., Condron, L.M., Peltzer, D.A., Richardson, S.J., Turner, B.L., 2007. Changes in enzyme activities and soil microbial community composition along carbon and nutrient gradients at the Franz Josef chronosequence, New Zealand. Soil Biol. Biochem. 39, 1770-1781.

Allison, S.D., Vitousek, P.M., 2005. Responses of extracellular enzymes to simple and complex nutrient inputs. Soil Biol. Biochem. 37, 937-944.

Badgley, C., Moghtader, J., Quintero, E., Zakem, E., Chappell, M.J., Aviles-Vazquez, K., Samulon, A., Perfecto, I., 2007. Organic agriculture and the global food supply. Renew. Agr. Food Syst. 22, 86-108. 
Birkhofer, K., Bezemer, T.M., Bloem, J., Bonkowski, M., Christensen, S., Dubois, D., Ekelund, F., Fliessbach, A., Gunst, L., Hedlund, K., Mader, P., Mikola, J., Robin, C., Setala, H., Tatin-Froux, F., Van der Putten, W.H., Scheu, S., 2008. Long-term organic farming fosters below and aboveground biota: implications for soil quality, biological control and productivity. Soil Biol. Biochem. 40, 2297-2308.

Borneman, J., Hartin, R.J., 2000. PCR primers that amplify fungal rRNA genes from environmental samples. Appl. Environ. Microb. 66, 4356-4360.

Borrelli, K., Koenig, R., Gallagher, R.S., Pittmann, D., Snyder, A., Burke, I., Hoagland, L., Fuerst, E.P., 2012. Alternative strategies for transitioning to organic production in direct-seeded grain systems in eastern Washington II: nitrogen fertility. J. Sustain. Agr. 36, 461-477.

Bremer, E., van Kessel, C., 1992. Seasonal microbial biomass dynamics after addition of lentil and wheat residues. Soil Sci. Soc. Am. J. 56, 1141-1146.

Burger, M., Jackson, L.E., 2003. Microbial immobilization of ammonium and nitrate in relation to ammonification and nitrification rates in organic and conventional cropping systems. Soil Biol. Biochem. 35, 29-36.

Castro, H.F., Classen, A.T., Austin, E.E., Norby, R.J., Schadt, C.W., 2010. Soil microbial community responses to multiple experimental climate change drivers. Appl. Environ. Microb. 76, 999-1007.

Choi, K.H., Dobbs, F.C., 1999. Comparison of two kinds of Biolog microplates (GN and ECO) in their ability to distinguish among aquatic microbial communities. J. Microbiol. Meth. 36, 203-213.

Culman, S.W., Bukowski, R., Gauch, H.G., Cadillo-Quiroz, H., Buckley, D.H., 2009. T-REX: software for the processing and analysis of T-RFLP data. BMC Bioinformatics 10, 171-181.

Culman, S.W., Gauch, H.G., Blackwood, C.B., Thies, J.E., 2008. Analysis of T-RFLP data using analysis of variance and ordination methods: a comparative study. J. Microbiol. Meth. 75, 55-63. 
Dick, W.A., Cheng, L., Wang, P., 2000. Soil acid and alkaline phosphatase activity as pH adjustment indicators. Soil Biol. Biochem. 32, 1915-1919.

Drinkwater, L.E., Wagoner, P., Sarrantonio, M., 1998. Legume-based cropping systems have reduced carbon and nitrogen losses. Nature 396, 262-265.

Duchicela, J., Sullivan, T.S., Bontti, E., Bever, J.D., 2013. Soil aggregate stability increase is strongly related to fungal community succession along an abandoned agricultural field chronosequence in the Bolivian Altiplano. J. Appl. Ecol. 50, 1266-1273.

Edwards, U., Rogal, T., Blöcker, H., Emde, M., Böttger, E.C., 1989. Isolation and direct complete nucleotide determination of entire genes. Characterization of a gene coding for $16 \mathrm{~S}$ ribosomal RNA. Nucleic Acids Res. 17, 7843-7853.

Ekenler, M., Tabatabai, M.A., 2002. $\beta$-glucosaminidase activity of soils: effect of cropping systems and its relationship to nitrogen mineralization. Biol. Fert. Soils 36, 367-376.

Esen, A., 1993. ß-Glucosidases: overview, in: Esen, A. (Ed.) Beta-Glucosidases: Biochemistry and Molecular Biology. American Chemical Society, Washington, DC, pp. 1-14.

Fliessbach, A., Oberholzer, H.R., Gunst, L., Mader, P., 2007. Soil organic matter and biological soil quality indicators after 21 years of organic and conventional farming. Agr. Ecosyst. Environ. 118, $273-284$.

Franke-Snyder, M., Douds, D.D., Galvez, L., Phillips, J.G., Wagoner, P., Drinkwater, L., Morton, J.B., 2001. Diversity of communities of arbuscular mycorrhizal (AM) fungi present in conventional versus low-input agricultural sites in eastern Pennsylvania, USA. Appl. Soil Ecol. 16, 35-48.

Gallagher, R.S., Pittmann, D., Snyder, A.M., Koenig, R.T., Fuerst, E.P., Burke, I.C., Hoagland, L., 2010. Alternative strategies for transitioning to organic production in direct-seeded grain systems in eastern Washington I: crop agronomy. J. Sustain. Agr. 34, 483-503. 
Gomez, E., Ferreras, L., Toresani, S., 2006. Soil bacterial functional diversity as influenced by organic amendment application. Bioresource Technol. 97, 1484-1489.

Gosling, P., Shepherd, M., 2005. Long-term changes in soil fertility in organic arable farming systems in England, with particular reference to phosphorus and potassium. Agr. Ecosyst. Environ. 105, $425-432$.

Gryndler, M., Larsen, J., Hrselova, H., Rezacova, V., Gyndlerova, H., Kubat, J., 2006. Organic and mineral fertilization, respectively, increase and decrease the development of external mycelium of arbuscular mycorrhizal fungi in a long-term field experiment. Mycorrhiza 16, 159-166.

Gunapala, N., Scow, K.M., 1998. Dynamics of soil microbial biomass and activity in conventional and organic farming systems. Soil Biol. Biochem. 30, 805-816.

Haynes, R.J., Naidu, R., 1998. Influence of lime, fertilizer and manure applications on soil organic matter content and soil physical conditions: a review. Nutr. Cycl. Agroecosys. 51, 123-137.

Kaplan, C.W., Kitts, C.L., 2003. Variation between observed and true terminal restriction fragment length is dependent on true TRF length and purine content. J. Microbiol. Meth. 54, 121-125.

Knight, T.R., Dick, R.P., 2004. Differentiating microbial and stabilized $\beta$-glucosidase activity relative to soil quality. Soil Biol. Biochem. 36, 2089-2096.

Lane, D.J., Pace, B., Olsen, G.J., Stahl, D.A., Sogin, M.L., Pace, N.R., 1985. Rapid determination of 16S ribosomal RNA sequences for phylogenetic analyses. Proc. Natl. Acad. Sci. 82, 6955-6959.

Lotter, D.W., 2003. Organic agriculture. J. Sustain. Agr. 21, 59-128.

Mader, P., Fliessbach, A., Dubois, D., Gunst, L., Fried, P., Niggli, U., 2002. Soil fertility and biodiversity in organic farming. Science 296, 1694-1697. 
Mahler, R.L., McDole, R.E., 1985. The influence of lime and phosphorus on crop production in northern Idaho. Commun. Soil Sci. Plant Anal. 16, 485-489.

Mahler, R.L., McDole, R.E., 1987. Effect of soil pH on crop yield in northern Idaho. Agron. J. 79, $751-755$.

Marinari, S., Mancinelli, R., Campiglia, E., Grego, S., 2006. Chemical and biological indicators of soil quality in organic and conventional farming systems in Central Italy. Ecol. Indic. 6, 701-711.

Marriott, E.E., Wander, M.M., 2006. Total and labile soil organic matter in organic and conventional farming systems. Soil Sci. Soc. Am. J. 70, 950-959.

Marsh, T.L., 1999. Terminal restriction fragment length polymorphism (T-RFLP): an emerging method for characterizing diversity among homologous populations of amplification products. Curr. Opin. Microbiol. 2, 323-327.

Marsh, T.L., 2005. Culture-independent microbial community analysis with terminal restriction fragment length polymorphism. Method Enzymol. 397, 308-329.

Martens, D.A., Johanson, J.B., Frankenberger, W.T., 1992. Production and persistence of soil enzymes with repeated addition of organic residues. Soil Sci. 153, 53-61.

Mason, H.E., Spaner, D., 2006. Competitive ability of wheat in conventional and organic management systems: a review of the literature. Can. J. Plant Sci. 86, 333-343.

Mitchell, T.G., Freedman, E.Z., White, T.J., Taylor, J.W., 1994. Unique oligonucleotide primers in PCR for identification of Cryptococcus neoformans. J. Clin. Microbiol. 32, 253-255.

Mulder, C., de Zwart, D., van Wijnen, H.J., Schouten, A.J., Breure, A.M., 2003. Observational and simulated evidence of ecological shifts within the soil nematode community of agroecosystems under conventional and organic farming. Funct. Ecol. 17, 516-525. 
Muthukumar, T., Udaiyan, K., 2000. Influence of organic manures on arbuscular mycorrhizal fungi associated with Vigna unguiculata (L.) Walp. in relation to tissue nutrients and soluble carbohydrate in roots under field conditions. Biol. Fert. Soils 31, 114-120.

Muyzer, G., de Waal, E.C., Uitterlinden, A.G., 1993. Profiling of complex microbial populations by denaturing gradient gel electrophoresis analysis of polymerase chain reaction-amplified genes coding for 16S rRNA. Appl. Environ. Microb. 59, 695-700.

Nannipieri, P., Ascher, J., Ceccherini, M.T., Landi, L., Pietramellara, G., Renella, G., 2003. Microbial diversity and soil functions. Eur. J. Soil Sci. 54, 655-670.

Oehl, F., Sieverding, E., Mader, P., Dubois, D., Ineichen, K., Boller, T., Wiemken, A., 2004. Impact of long-term conventional and organic farming on the diversity of arbuscular mycorrhizal fungi. Oecologia 138, 574-583.

Parfitt, R.L., Ross, D.J., Coomes, D.A., Richardson, S.J., Smale, M.C., Dahlgren, R.A., 2005. N and P in New Zealand soil chronosequences and relationships with foliar N and P. Biogeochemistry 75, $305-328$.

Parham, J.A., Deng, S.P., 2000. Detection, quantification and characterization of $\beta$-glucosaminidase activity in soil. Soil Biol. Biochem. 32, 1183-1190.

Peoples, M.B., Brockwell, J., Herridge, D.F., Rochester, I.J., Alves, B.J.R., Urquiaga, S., Boddey, R.M., Dakora, F.D., Bhattarai, S., Maskey, S.L., Sampet, C., Rerkasem, B., Khan, D.F., HauggaardNielsen, H., Jensen, E.S., 2009. The contributions of nitrogen-fixing crop legumes to the productivity of agricultural systems. Symbiosis $48,1-17$.

Posner, J.L., Baldock, J.O., Hedtcke, J.L., 2008. Organic and conventional production systems in the Wisconsin Integrated Cropping Systems Trials: I. productivity 1990-2002. Agron. J. 100, 253-260. 
Puget, P., Angers, D.A., Chenu, C., 1999. Nature of carbohydrates associated with water-stable aggregates of two cultivated soils. Soil Biol. Biochem. 31, 55-63.

Reardon, C.L., Wuest, S.B., 2016. Soil amendments yield persisting effects on the microbial communities - a 7-year study. Appl. Soil Ecol. 101, 107-116.

Ros, M., Klammer, S., Knapp, B., Aichberger, K., Insam, H., 2006. Long-term effects of compost amendment of soil on functional and structural diversity and microbial activity. Soil Use Manage. 22, 209-218.

Rousk, J., Baath, E., Brookes, P.C., Lauber, C.L., Lozupone, C., Caporaso, J.G., Knight, R., Fierer, N., 2010. Soil bacterial and fungal communities across a pH gradient in an arable soil. ISME J. 4, 1340-1351.

Seufert, V., Ramankutty, N., Foley, J.A., 2012. Comparing the yields of organic and conventional agriculture. Nature 485, 229-232.

Shannon, D., Sen, A.M., Johnson, D.B., 2002. A comparative study of the microbiology of soils managed under organic and conventional regimes. Soil Use Manage. 18, 274-283.

Sinsabaugh, R.L., 1994. Enzymic analysis of microbial pattern and process. Biol. Fert. Soils 17, 69-74.

Sinsabaugh, R.L., Moorhead, D.L., 1995. Resource allocation to extracellular enzyme production: a model for nitrogen and phosphorus control of litter decomposition. Soil Biol. Biochem. 26, 1305-1311.

Smith, C.J., Danilowicz, B.S., Clear, A.K., Costello, F.J., Wilson, B., Meijer, W.G., 2005. T-Align, a web-based tool for comparison of multiple terminal restriction fragment length polymorphism profiles. FEMS Microbiol. Ecol. 54, 375-380. 
Stott, D.E., Andrews, S.S., Liebig, M.A., Wienhold, B.J., Karlen, D.L., 2009. Evaluation of $\beta$-glucosidase activity as a soil quality indicator for the soil management assessment framework. Publications for USDA-ARS, UNL Faculty. Paper 1222. http://digitalcommons.unl.edu/usdaarsfacpub/1222 (accessed 26.02.16).

Tabatabai, M.A., 1994. Soil Enzymes, Methods of Soil Analysis, Part 2. Microbiological and Biochemical Properties. Soil Science Society of America, Madison, WI, pp. 775-833.

Tautges, N.E., Goldberger, J.R., 2015. Summary report: a survey of certified organic producers in the western United States: experiences and management practices of growers in Idaho, Montana, Oregon, Utah, and Washington. CAHNRS and WSU Extension Wheat and Small Grains, Washington State University. http://smallgrains.wsu.edu/results-of-the-2014-survey-ofnorthwestern-organic-producers/ (accessed 19.02.16).

Tu, C., Ristaino, J.B., Hu, S., 2006. Soil microbial biomass and activity in organic tomato farming systems: effects of organic inputs and straw mulching. Soil Biol. Biochem. 38, 247-255.

Van Diepeningen, A.D., de Vos, O.J., Korthals, G.W., van Bruggen, A.H., 2006. Effects of organic versus conventional management on chemical and biological parameters in agricultural soils. Appl. Soil Ecol. 31, 120-135.

Walz, E., 2004. Final results of the fourth national organic farmers' survey: sustaining organic farms in a changing organic marketplace. Organic Farming Research Foundation, Santa Cruz, CA. http://ofrf.org/sites/ofrf.org/files/docs/pdf/4thsurvey_results.pdf. (accessed 28.02.16).

Willson, T.C., Paul, E.A., Harwood, R.R., 2001. Biologically active soil organic matter fractions in sustainable cropping systems. Appl. Soil Ecol. 16, 63-76. 
Xavier, L.J.C., Germida, J.J., 2003. Selective interactions between arbuscular mycorrhizal fungi and Rhizobium leguminosarum bv. viceae enhance pea yield and nutrition. Biol. Fert. Soils 37, 261-267.

Yeates, G.W., Bardgett, R.D., Cook, R., Hobbs, P.J., Bowling, P.J., Potter, J.F., 1997. Faunal and microbial diversity in three Welsh grassland soils under conventional and organic management regimes. J. Appl. Ecol. 34, 453-470.

Zentner, R.P., Campbell, C.A., Biederbeck, V.O., Selles, F., Lemke, R., Jefferson, P.G., Gan, Y., 2004. Long-term assessment of management of an annual legume green manure crop for fallow replacement in the Brown soil zone. Can. J. Plant Sci. 84, 11-22. 


\section{Captions}

Table 1. Soil total C and N from 2014 soil sampling (microbial analysis), and pooled over all study years (2009 to 2014) during which soil sampling was performed. P-values are the results of an ANOVA test with System as a fixed effect

Table 2. Plant productivity means comparisons between organic and conventional systems in replicates were planted to either spring wheat or winter peas in 2014. P-values are the results of a one-way ANOVA test with System as a fixed effect

Table 3. Substrate utilization on Biolog Ecoplates ${ }^{\mathrm{TM}}$ inoculated with soil from both cropping systems. Substrates depicted are those where differences in substrate utilization patterns were detected between cropping systems. Well color development is the optical density values of plate wells read at $590 \mathrm{~nm}$, where greater optical density represents greater substrate utilization.

Table 4. Enzyme activities ( $\mu \mathrm{g}$ nitrophenol $\mathrm{g}^{-1}$ dry soil $\mathrm{hr}^{-1}$ ) in 0 to $15 \mathrm{~cm}$ fraction of soils from organic and conventional system soils. P-values are the results of an ANOVA test with System as a fixed effect

Fig. 1. Bacterial and fungal rRNA and ITS gene copy numbers, respectively, averaged across replicate plots within cropping systems depicted on left vertical axis, and fungal to bacterial copy number ratio depicted on the right vertical axis. Bact $=$ bacteria $; \mathrm{ORG}=$ organic system $; \mathrm{CONV}=$ conventional system; $\mathrm{SW}=$ spring wheat; $\mathrm{WP}=$ winter pea. Bars indicate the standard error of the mean $(n=5)$ 
Fig. 2. Relationship of pea hay dry matter yields in the organic and conventional systems with a) fungal abundance and b) bacterial abundance (rRNA gene copy numbers). Regression analysis was performed using data from all plots. A log transformation was used to stabilize unequal variances of fungal and bacterial gene copy numbers. $\mathrm{ORG}=$ organic system; $\mathrm{CONV}=$ conventional system

Fig. 3. Carbon substrate utilization by soil microbes in organically-managed (ORG) and conventionallymanaged (CONV) soils measured on BIOLOG Ecoplates ${ }^{\mathrm{TM}}$ after $72 \mathrm{~h}$ of incubation. Error bars indicate the standard error of the mean $(n=5)$

Fig. 4. Non-metric multidimensional scaling (NMS) analysis of carbon substrate utilization on BIOLOG plates by soil microbial communities in the organic and conventional systems. Points on the graph represent the entire amplified bacterial or fungal community composition of the soils of the replicate plots. Gray lines display joint-plot vectors of soil total $\mathrm{N}$ and soil $\mathrm{pH}$, which had $\mathrm{r}^{2}$ values $>0.40$. Ordination final stress was $9.4 . \mathrm{ORG}=$ organic system; $\mathrm{CONV}=$ conventional system; $\mathrm{SW}=$ spring wheat; WP = winter pea

Fig. 5. Pea tissue percent $\mathrm{N}$ versus bacterial utilization of the substrates a) D-cellobiose and b) glucose-1phosphate. Substrate utilization is in units of optical density, read at $590 \mathrm{~nm}$, where greater optical density represents greater substrate utilization

Fig. 6. Non-metric multidimensional scaling (NMS) analysis of bacterial T-RFLP in the organic and conventional systems. Points on the graph represent the entire amplified bacterial or fungal community composition of the soils of the replicate plots. The gray line displays the joint-plot vector of soil $\beta$ - 
glucosidase $(\mathrm{GP})$ concentration, which had an $\mathrm{r}^{2}$ value $>0.40$. Ordination final stress was $14.5 . \mathrm{ORG}=$ organic system; $\mathrm{CONV}=$ conventional system; $\mathrm{SW}=$ spring wheat $; \mathrm{WP}=$ winter pea

Fig. 7. Non-metric multidimensional scaling (NMS) analysis of fungal T-RFLP in the organic and conventional systems. Points on the graph represent the entire amplified bacterial or fungal community composition of the soils of the replicate plots. The gray line displays the joint-plot vector of grain yield, which had an $\mathrm{r}^{2}$ value $>0.40$. Ordination final stress was $11.0 . \mathrm{ORG}=$ organic system; $\mathrm{CONV}=$ conventional system; $\mathrm{SW}=$ spring wheat; $\mathrm{WP}=$ winter pea

Fig. 8. Relationship of spring wheat grain percent protein in the organic and conventional systems with $\beta$ glucosaminidase activity in soils 
Table 1. Soil total C and N from 2014 soil sampling (microbial analysis), and pooled over all study years (2009 to 2014) during which soil sampling was performed. P-values are the results of an ANOVA test with System as a fixed effect

\begin{tabular}{|c|c|c|c|c|c|c|}
\hline & \multirow[t]{2}{*}{ Year } & \multicolumn{2}{|c|}{ Organic } & \multicolumn{2}{|c|}{ Conventional } & \multirow{2}{*}{$\begin{array}{c}\text { Contrast } \\
\text { p-value }\end{array}$} \\
\hline & & $(\%)$ & $\mathrm{sd}^{\dagger}$ & $(\%)$ & $\mathrm{sd}$ & \\
\hline \multirow{2}{*}{ TC } & 2014 & 1.86 & 0.33 & 1.69 & 0.24 & 0.148 \\
\hline & 2009-2014 & 1.93 & 0.31 & 1.75 & 0.21 & $<0.001$ \\
\hline \multirow{2}{*}{ TN } & 2014 & 0.157 & 0.052 & 0.194 & 0.097 & 0.199 \\
\hline & 2009-2014 & 0.160 & 0.032 & 0.153 & 0.047 & 0.262 \\
\hline
\end{tabular}

${ }^{\dagger} \mathrm{sd}=$ standard deviation of the mean 
Table 2. Plant productivity means comparisons between organic and conventional systems in replicates were planted to either spring wheat or winter peas in 2014. P-values are the results of a one-way ANOVA test with System as a fixed effect

\begin{tabular}{|c|c|c|c|c|}
\hline \multirow[t]{2}{*}{ Crop } & \multirow[t]{2}{*}{ Productivity $^{\dagger}$} & \multicolumn{2}{|c|}{ System } & \multirow[t]{2}{*}{$\mathbf{P}>\mathbf{F}$} \\
\hline & & Organic & Conventional & \\
\hline \multirow{2}{*}{$\begin{array}{l}\text { Spring } \\
\text { Wheat }\end{array}$} & Yield (kg ha $\left.{ }^{-1}\right)$ & 2300 & 3465 & 0.007 \\
\hline & Grain protein $(\%)$ & 13.75 & 14.60 & 0.016 \\
\hline \multirow{2}{*}{$\begin{array}{l}\text { Winter } \\
\text { Peas }\end{array}$} & $\begin{array}{c}\text { Hay yield } \\
\left.(\mathrm{kg} \mathrm{DM} \mathrm{ha})^{-1}\right)\end{array}$ & 4490 & 2505 & 0.004 \\
\hline & Tissue N (\%) & 2.90 & 2.30 & 0.022 \\
\hline
\end{tabular}

${ }^{\dagger} \mathrm{DM}=$ dry matter 
Table 3. Substrate utilization on Biolog Ecoplates ${ }^{\mathrm{TM}}$ inoculated with soil from both cropping systems. Substrates depicted are those where differences in substrate utilization patterns were detected between cropping systems. Well color development is the optical density values of plate wells read at $590 \mathrm{~nm}$, where greater optical density represents greater substrate utilization.

\begin{tabular}{|c|c|c|c|}
\hline Substrate & Organic & Conventional & \multirow[t]{2}{*}{ p-value ${ }^{T}$} \\
\hline & \multicolumn{2}{|c|}{ Well Color Development } & \\
\hline$\alpha$-D-Lactose & 1.42 & 0.49 & 0.001 \\
\hline$\alpha$-Cyclodextrin & 1.37 & 0.27 & $<0.001$ \\
\hline Glycogen & 1.36 & 0.33 & $<0.001$ \\
\hline D-Cellobiose & 2.17 & 1.13 & $<0.001$ \\
\hline Glucose-1-Phosphate & 1.36 & 0.50 & 0.001 \\
\hline D-Xylose & 2.05 & 1.46 & 0.059 \\
\hline Phenylethyl-amine & 1.60 & 0.70 & 0.003 \\
\hline B-Methyl-D-Glucoside & 1.36 & 0.91 & 0.085 \\
\hline D-Malic Acid & 1.34 & 0.44 & $<0.001$ \\
\hline i-Erythritol & 1.37 & 0.84 & 0.016 \\
\hline D-Galactonic Acid y-Lactone & 1.73 & 1.39 & 0.065 \\
\hline N-Acetyl-D-Glucosamine & 2.21 & 1.82 & 0.013 \\
\hline Itaconic Acid & 2.06 & 1.71 & 0.010 \\
\hline Glycyl-L-Glutamic Acid & 0.81 & 0.51 & 0.039 \\
\hline L-Asparagine & 2.45 & 2.56 & 0.017 \\
\hline L-Phenylalanine & 0.98 & 0.75 & 0.020 \\
\hline
\end{tabular}

${ }^{\Phi} \mathrm{p}<0.10$ was considered significant 
Table 4. Enzyme activities ( $\mu \mathrm{g}$ nitrophenol $\mathrm{g}^{-1}$ dry soil $\mathrm{hr}^{-1}$ ) in 0 to $15 \mathrm{~cm}$ fraction of soils from organic and conventional system soils. P-values are the results of an ANOVA test with System as a fixed effect

\begin{tabular}{cccc}
\hline Enzyme Activity & Organic & Conventional & p > F \\
\cline { 2 - 3 } & \multicolumn{1}{c}{$\mu \mathrm{NP} \mathrm{g}^{-1} \mathrm{dry} \mathrm{soil} \mathrm{hr}^{-1}$} & \\
\cline { 2 - 4 } Acid Phosphatase & 266 & 260 & 0.858 \\
$\beta$-glucosidase & 86 & 61 & 0.111 \\
$\beta$-glucosaminidase & 36 & 24 & 0.009 \\
\hline
\end{tabular}




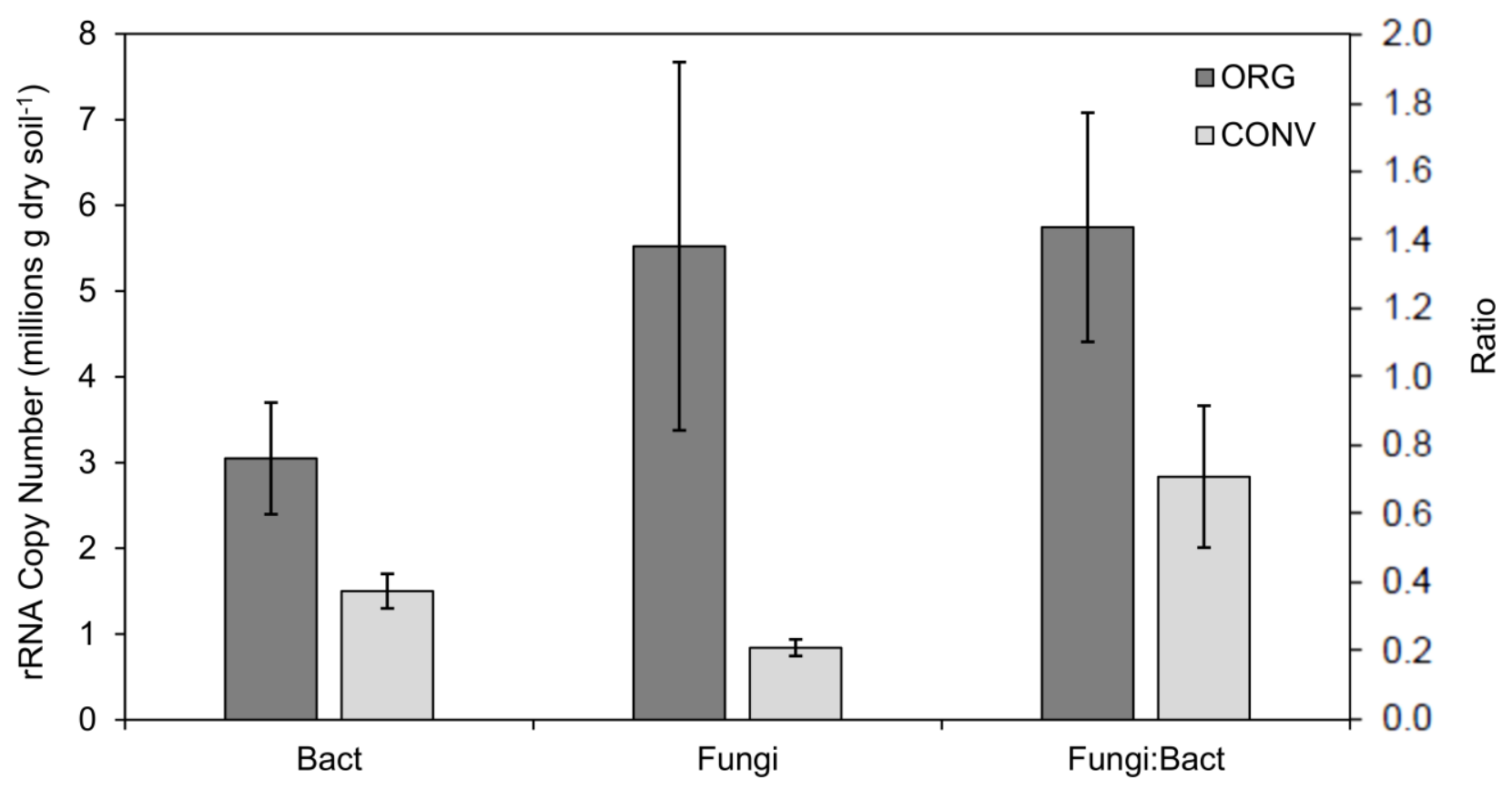



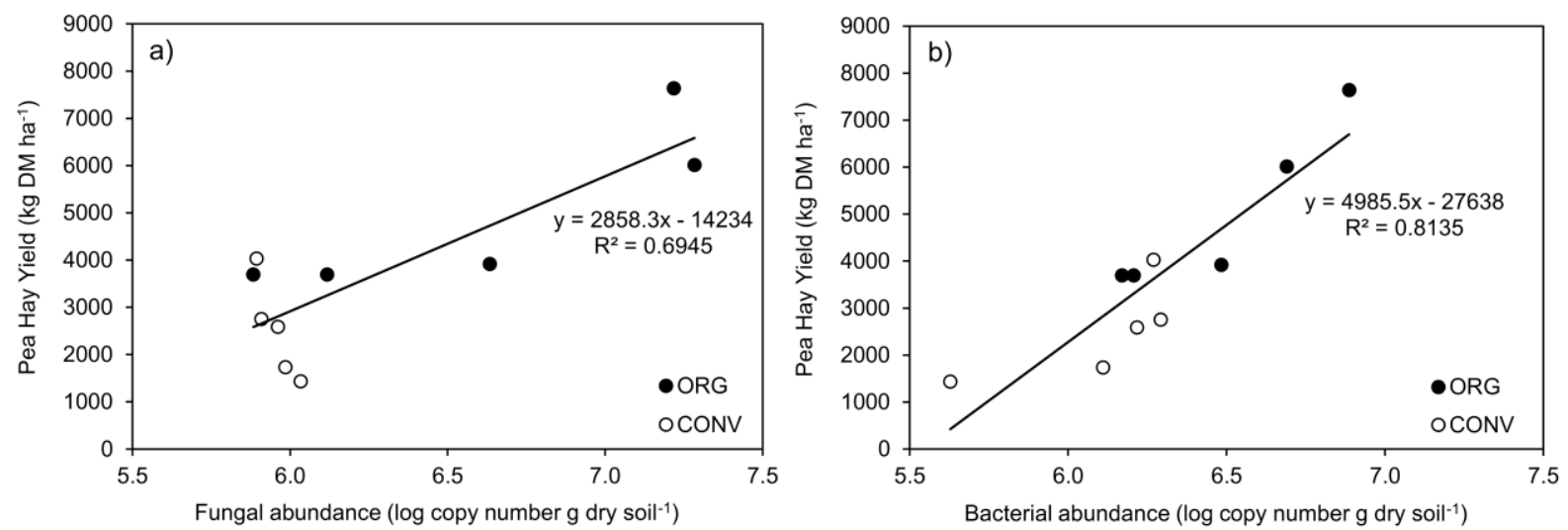


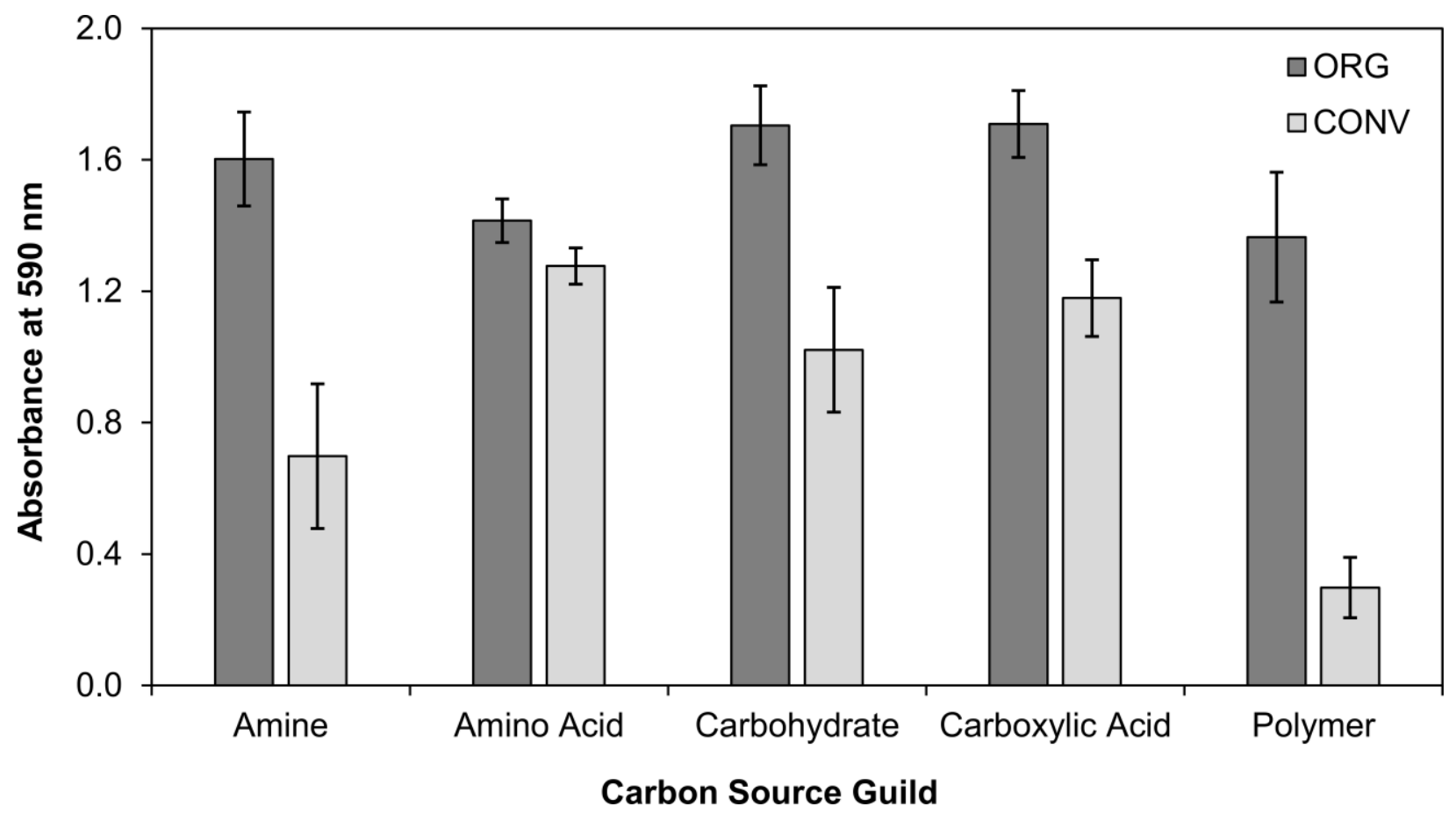




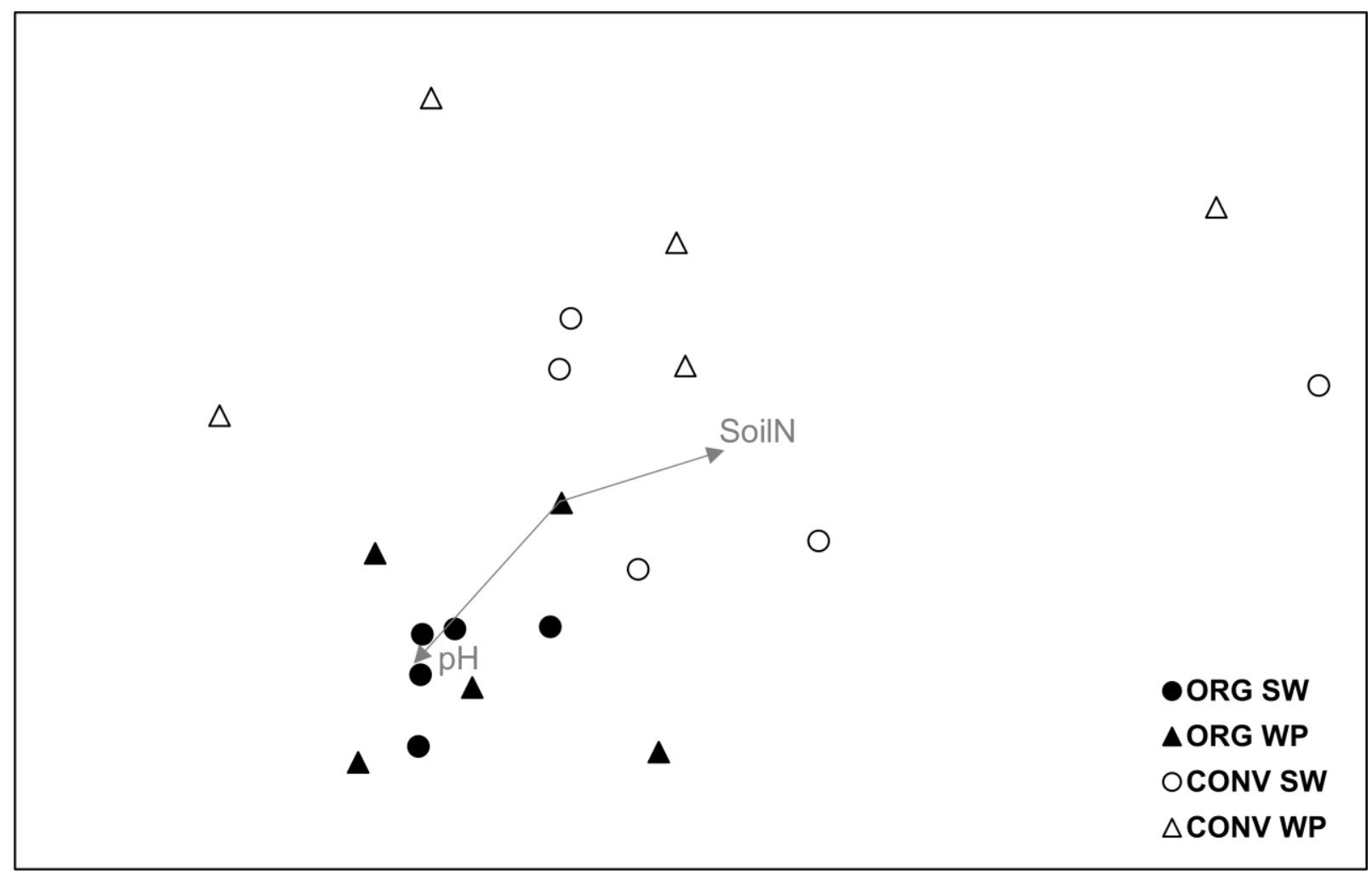



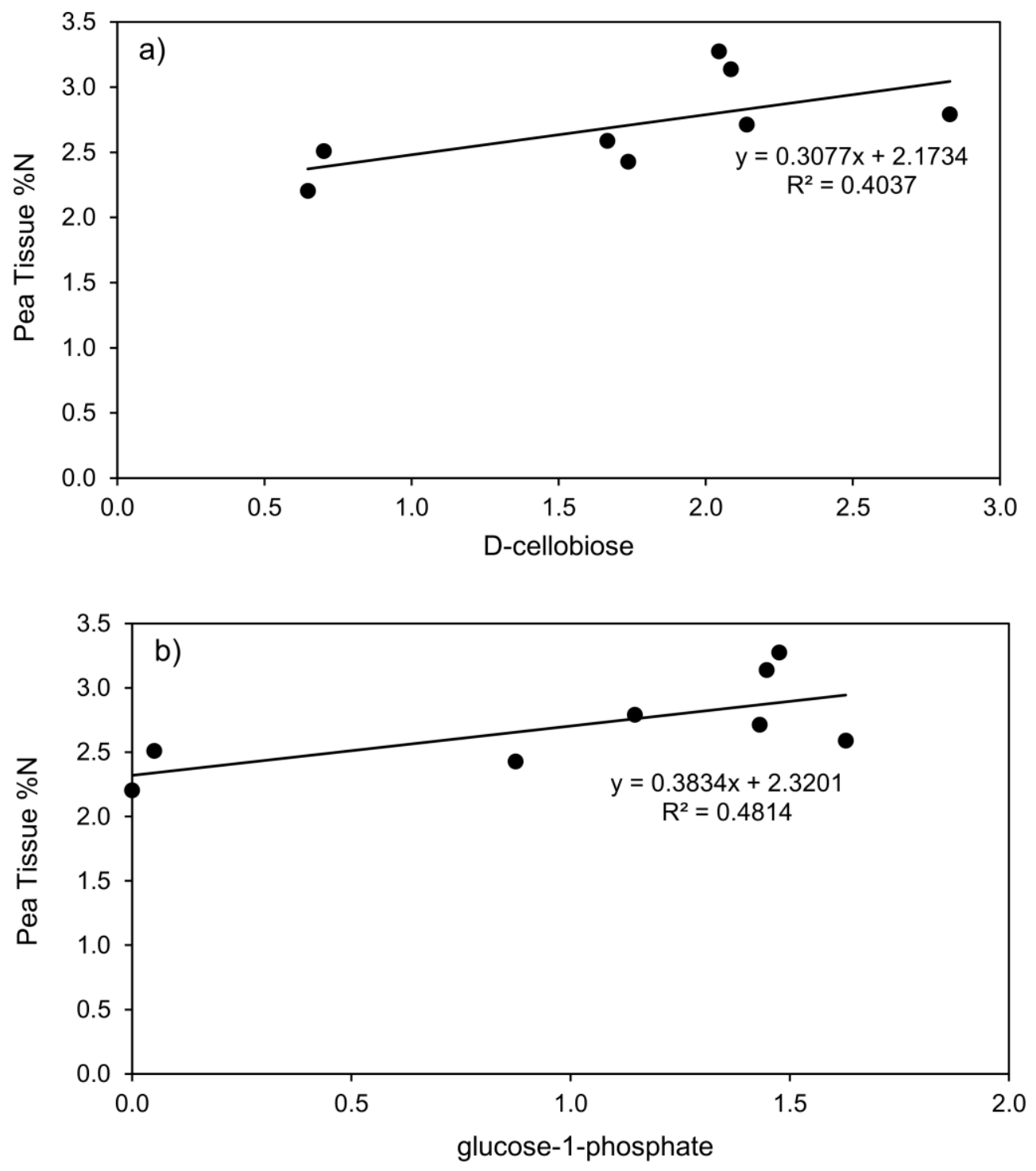


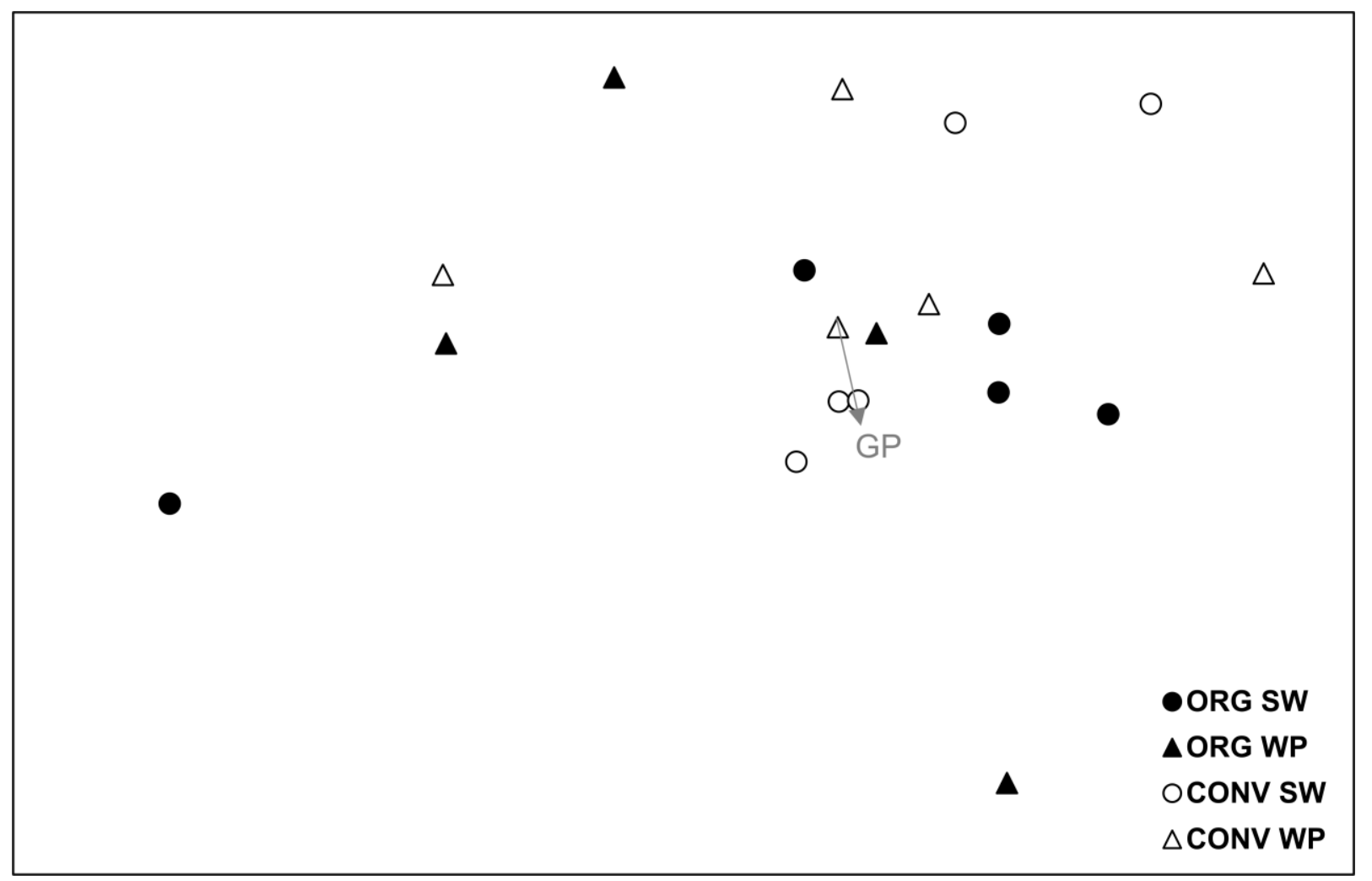




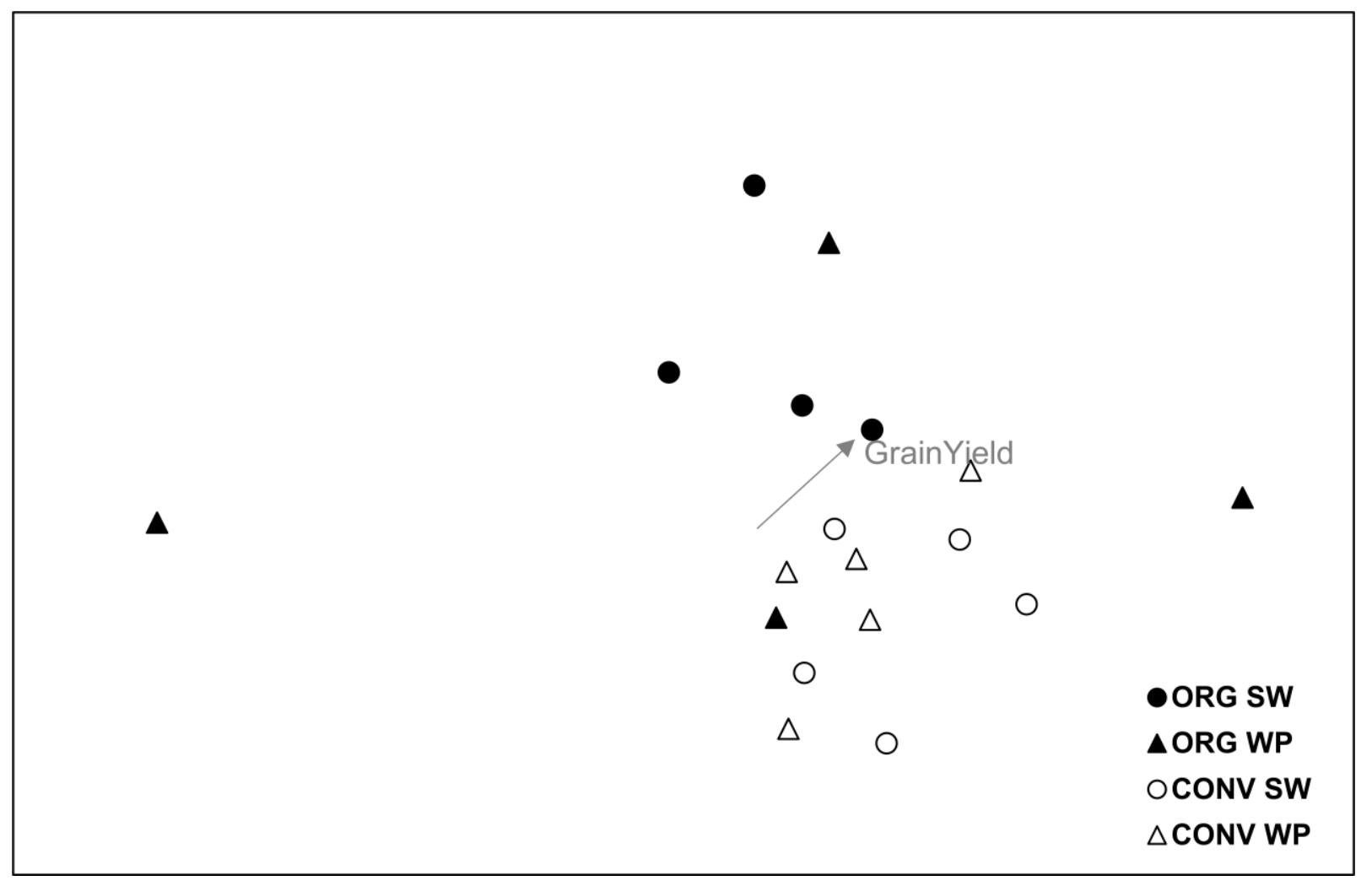




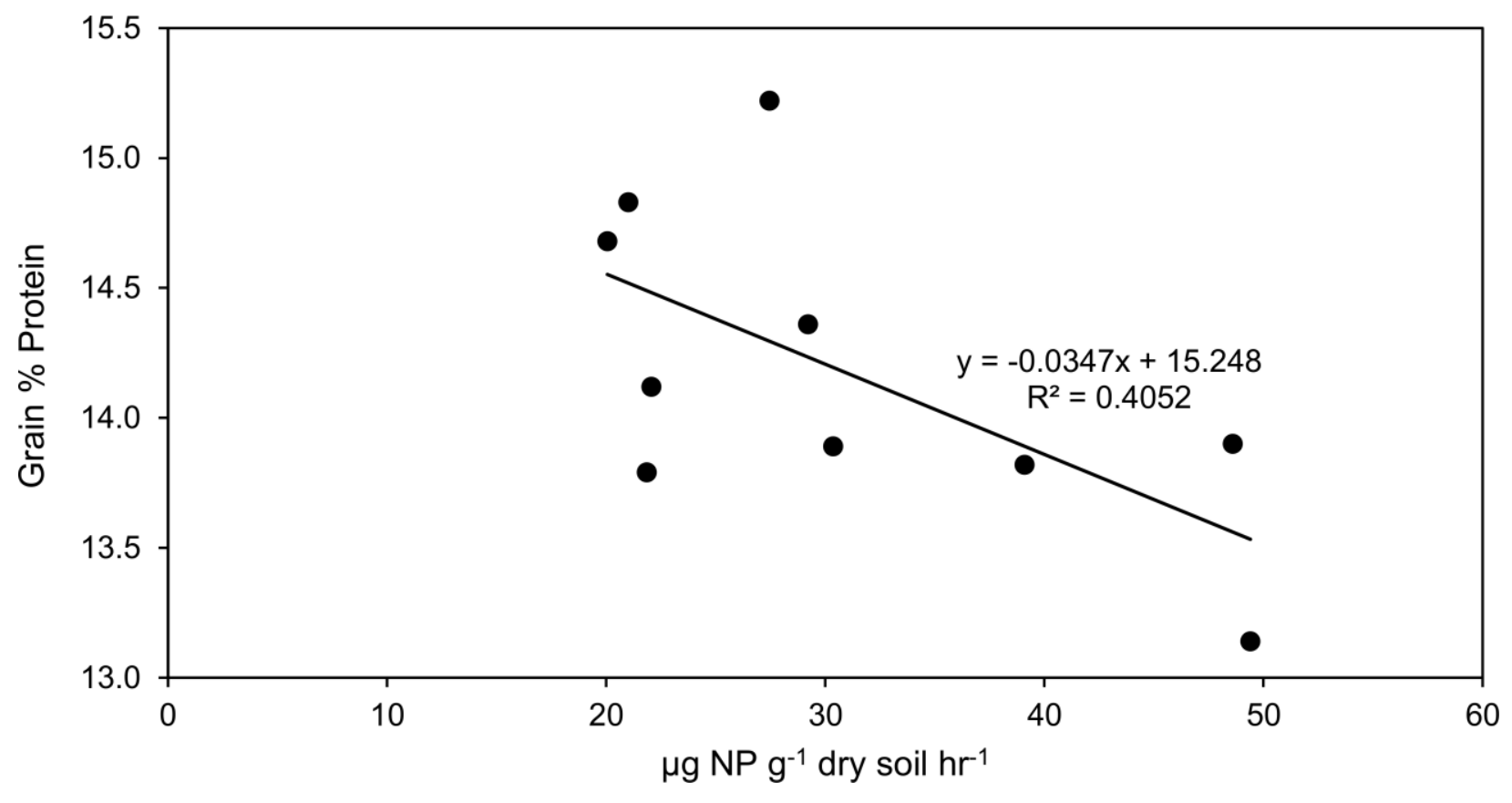

